\title{
The Other Side of the Internet: Power, Commodification and Information Technology
}

\author{
Rafael Rodríguez Prieto
}

\begin{abstract}
The Internet is a powerful tool to spread economic development and communications. However, the rules of the information highway are made by a handful of global corporations with little public oversight. The internet is about big companies owning and controlling so much of what should public property, but in fact the entire internet could be a private property. I will devote my paper to an analysis of the roots and rise of the different power constellations currently seeking circumscription of the Internet on a global scale. I close with a few conclusions about Internet and democracy.
\end{abstract}

Index Terms - Cyberspace, internet, power, participation.

\section{INTRODUCTION}

Internet is much more than a technology, or a communications platform. It has become a symbol; something positive, per se. Speaking ill of the Internet is done at risk of being labeled a neo-Luddite and all but ostracized by the vast majority of your fellow citizens. The Web is simply a natural part of life. In certain circles, not having a WhatsApp, Facebook or Twitter account (or more elite equivalent) is as weird as walking naked down the street. Internet is good, positive, young and dynamic. Adulation of the digital is so absolute that any product produced or purchased via the Web is seen as not only as intrinsically positive, but even liberating, redemptive. Online services boast a pristine public image. They save us paper, which makes trees in the Amazon happy. But they also make it a cinch to share photos with our friends of the mouthwatering dish we just created on our new ceramic cooktop, or to plan the next revolution from our living room sofa; whatever turns you on.

It is, perhaps, the intoxicating way we identify ourselves with the Web which in some way explains the shock people experience when they read or hear news like we have been reminded of in recent months: reports detailing continent-spanning company and government spying schemes, or wholesale efforts to control online information, communication and content; Web-based monopolies and the tremendous exploitation perpetrated by firms at the highest levels of online aristocracy; ongoing erosion of personal privacy, or tax fraud using loopholes in Internet legislation.

These are just a few examples of how current events have marred the otherwise Photoshop-perfect face of Internet and some of its most prominent players. It seems many people still fail to reflect on the fact that when we use the Web we

Manuscript received May 30, 2016; revised March 14, 2017.

Rafael Rodríguez Prieto is with the University of Seville, Spain (e-mail: rrodpri@upo.es). are almost always signing terms of use agreements with private companies; companies to whom we sign away very relevant data about our public and private lives, in exchange for nothing. It is as if we closed our eyes and imagined that Internet is made and managed out of thin air, as ethereal as the clouds themselves. Quite the contrary. In fact, the Web is solid. Brick solid. And it has owners.

Underpinning the ideas presented here is the aspiration to achieve a counterpoint, of sorts, in the discussion. Hence, while in no way detracting from the value of more issue-centered scholarly efforts, I will do research to the beat of a different drum with a view to take the discussion to another level; one which allows us to understand Internet in ways in which case-by-case analysis of the Web does not. To this end, I will devote my paper to an analysis of the roots and rise of the different power constellations currently seeking circumscription of the Internet on a global scale. I close with a few conclusions about Internet and democracy.

\section{POWER AND COMMODIFICATION OF THE INTERNET}

Upload speed is a factor which fosters optimism towards the Internet. It multiplies our potential and turns us into producers and collaborators. The revolting rift between appropriators and producers closes to some extent due to cybernetic trends inspired by values divorced from the socio-economic —and, above all, cultural-hegemony of capitalism.

Optimism is a good thing; but idolizing it is not. Internet has shown us its spying brawn, capacity to control, tendency to become a tool in the hands of those who actively deny the above. In the post-Snowden era the question is no longer whether we are spied on, but who decides how the vast amount of information they have on us is used.

The short film, what's on your mind? (Whose title makes reference to Facebook's status update function) was presented at this year's Cannes Film Festival and caused quite a stir. It tells the story of someone who always posts positive messages and photos-and is rewarded with successive "likes" - in stark contrast with the sad, frustration-laden life the person actually leads. This short film portrays two of the basic threats Internet poses. The first is obvious: the Web as a new form of confinement that leads to unhappiness. The second pitfall is to confuse the wide range of opportunities Internet puts at our fingertips, with the services of mammoth online companies like Facebook. This and other Internet empires are multinational corporations, strongly rooted in anarcho-capitalist political philosophy and designed to feast on the cornucopia of personal information we provide them. Not that Facebook — or any other major online player, for that 
matter-is the Web's version of the bogeyman. The Internet and its services simply should not be used with a blindfold on; it is not in our best interest to accept and naturalize processes or realities resulting from relations of power and domination

Locating the next Silicon Valley has become an obsession. No political or business leader in their right mind would hesitate to leverage the legend to promote an agenda or their own campaign. Every era has had its reincarnation, its Valley of Silicon-Jerusalem, Rome, Constantinople, Granada, London-a geographical techno-mythology of sorts; a crossroads of realities. Silicon Valley is synonymous with cutting-edge corporations, bike lanes and projects whose mission is to make life easier. But it is also a breeding ground for companies encouraging female employees to freeze their eggs and postpone motherhood, entrepreneurs who abhor the homeless and helpless, and a booming housing market that closes the door on hundreds of thousands of people. MIT Technology Review editor, David Rotman, points out that 20-25 percent of Silicon Valley's population work in the lucrative high tech sector-and wealth is almost exclusively in their hands; the upshot: housing, transport and living costs are skyrocketing. At the same time, we witness a growing number of low-paying jobs in sales, foodservice, and manual labor. Chris Benner, Director of the Everett Program for Digital Tools for Social Innovation, asserts that digital technologies facilitate making billions of dollars with bare bones investment in human resources [1].

Back to freezing eggs for a future pregnancy: the idea may seem advantageous - and so it was portrayed in the media. Yet it is just another example of the kind of discrimination women seeking career advancement face in a world where presumably they are treated as equals. Apple and Facebook take for granted that motherhood is a nuisance; a disease of sorts that can lead to termination of a contract. It is, perhaps, a more refined form of patriarchy but, at the end of the day, just as marginalizing, just as discriminatory. The reasonable 21st century assumption would be that motherhood is a woman's right-fully compatible with career success - the fruit of which benefits society as a whole. Not the case: maternity is increasingly subject to corporate profit margins. Women postpone parenting indefinitely in their quest for promotion; or the eventual career change.

The business opportunities the Internet affords are a seductive selling point. Toomas Hendrik, President of Estonia, wants to make e-residence the economic engine of his country. This would imply that anyone could become an e-citizen in a country they did not reside simply by fulfilling a (rather lax) series of prerequisites; according to government estimates there could be as many as 10 million e-Estonians by 2025. Estonia is the country of Skype, Transferwise and Kazaa-and in 2007 became the first country to authorize online voting. It has one of the fastest Internet connections in Europe, along with Lithuania and Romania. Yet this burgeoning e-business scene goes hand in hand with a mushrooming mafia network which find itself right at home in the Baltic states and parts of eastern Europe such as the Ukraine. Cybercrime is a very real, constant threat. Yet more often than not it gets a veil of digital devotion as politicians and businessmen scramble to hustle their agendas to voters and the world. Silicon Valley and Al Capone's Chicago are only a click apart.

Internet's industrial substratum is not as harmless to society — or the environment—as they would like us to think. Quincy is a small town in Washington State surrounded by lakes. In 2006, Microsoft bought seventy-five acres of land just outside Quincy. The company was attracted by the number of hydropower plants in the area, the price of land and the tax breaks. The area-hit hard by unemployment—saw in Microsoft the gleam of opportunity, the promise of progress. It did not take long, however, for a citizens group to sue the megacorp for pollution from the diesel generators it had deployed to power its data centers. Each generator stands about 10 feet $(3 \mathrm{~m})$ tall and weighs several tons (thousands of kg). Such devices are also known to release carcinogens into the atmosphere [2].

Internet is a technology platform that builds reality and that, in turn, is built within the framework of politically significant trends and processes. Critical analysis of this ever-changing reality is essential: how it is designed, deployed, developed-in short, a comprehensive understanding of the wide range of processes the Internet generates. Challenges such as cyber spying, corporate monopoly, privacy breaches, limits on upload speed, misuse of our digital footprint, Net Neutrality or tax evasion by online megacorps are all concerns which tend to be addressed in a very disjointed, piecemeal manner-both by the media and academia. Aristotelian segmentation of knowledge in airtight compartments and the lack of a comprehensive analysis of Internet's complexity foil a full understanding of online processes.

The processes discussed thus far coexist with others; processes that show the enormous range of opportunities for improving peoples' physical and emotional circumstances made possible or enhanced by Internet. The use of the Internet to drive democratic change, grass-roots participation, independent social networks, a wide range of humanitarian and volunteer projects, creative endeavors, alternatives to 9-to-5 employment and self-management and are just a few examples of this.

Margarita Padilla argues that Internet is comprised of three components that give it a very specific relevance for use by social movements: ambiguity, uncontrollability and openness. For Padilla, "Internet is ambiguous because it was not designed for any particular use, and therefore can adapt to all conceivable uses. It is uncontrollable, as the intelligence and capacity for action are in each of the nodes that comprise it. And it is open because, on one hand, any knowledgeable person can read the source code and, on the other, anyone operating as a network can connect instantly"[3].

Padilla's ideas begin to explain the essential role Internet plays in the development of social movements and what they stand to gain from the possibilities the Web offers. We are looking at a very real opportunity for social transformation.

Internet's inherent ambiguity, as observed by Padilla, is reflected in the primordial, free exchange of knowledge and information. Prior to 1990, The National Science Foundation Network explicitly limited Internet use to non-commercial purposes. The foundation's internal policy was underpinned by the notion that public/democratic spheres and trade do not mix. However, a lack of serious debate coupled with the 
relentless hegemony of neoliberal factions, paved the way for free-market rhetoric_-championed by large corporations with a penchant for monopoly-to invade the Web [4]. Despite the onslaught of radical commodification, we can affirm today that the Internet still lends itself to a wide variety of uses.

Uncontrollability is essentially linked to the establishment of power networks, and their transformation into relationships of domination. Such relationships are interconnected and are clearly power relationships_-inherent to human relationships. Internet is a very effective tool when it comes to preventing them from becoming relationships of domination. According to Padilla, node structures disseminate information and knowledge - facilitating the sharing of processes, not only of results, while avoiding a totalizing center. Movements in favor of free software, Net Neutrality and imposing limits on intellectual property-and against the control of governments and large corporations - are part of the uncontrollability of Internet.

However, as occurred in modern Europe, pro private property forces face off with antithetical forces which seek to avoid mass privatization by defending a common ground. The communal and the private clash again, centuries later, in a battle of tremendous economic, political, social and cultural consequences. We are front-line spectators of a struggle we expect will have a dramatic impact on the demarcation of values and ideas, politics and the economy, for years to come. The outcome will determine the shape, not only of the Internet, but of the whole of society as we know it. It is essential, then, to reconsider the idea of control in the current context; old approaches are no longer legitimate. If the control exercised by nation-states was a concern, the tech revolution has brought a whole new arsenal of privately developed power tools to the table-at least as hazardous as their predecessors, if not much more so.

In this vein, Lawrence Lessig's thesis on how the Internet operates comes to mind. In The Code [6], the message is clear: the Internet does not have a set shape, per se but is contingent on a series of dynamic factors. These factors underlie the arenas where the war over the totalizing role of the Internet itself is waged. The outcome of this battle determines the horizon of possibility at any given moment. If the Internet is not-nor ever was-controllable from the standpoint of a governing core it is because, from its very birth, there has been an ongoing struggle to shape it in one way or another. It is interesting to see the direction things are drifting: further and further away from a can-do-no-wrong view of the Internet. The PRISM program in the US, wholesale spying in Germany or the INDECT project at the European level are just a few examples of why this is so.

Internet has played a major role in the consolidation of this type of, highly effective, informal control. As the Ippolita Collective reminds us, the upshot of Google's enormous success is that a private company manages an unprecedented amount of public knowledge and data [7]. Internet giants like Facebook and Google leverage networks of domination made possible, in part, by the users themselves, who willingly open the door to the exploitation of their digital footprint. Citizens invest a large part of their social capital, of their time, in this cyber-world; this investment serves to finance these companies and, in so doing, deepen their control and facilitate the emergence of an increasingly powerful technocracy.

Max Weber's thinking on types of domination provides a framework for locating such behavior within the power grid generated by Internet. The German theorist understood that the most important factor in the stability of systems of domination is the obedience of subordinates; and that obedience reaches its highest expression when subordinates adopt the content of the order itself as their guideline for behavior. While surely it was never Weber's intention, it seems his ideas can be applied with practically no modification to the context under analysis.

Another key factor is government-sponsored surveillance. One of the latest cases of government control over communications is construction of the Utah Data Center, designed to allow the NSA to store, process and analyze unprecedented volumes of information from domestic and international surveillance operations [8] So it is not all about talking on the Net. Listening is important too; and perhaps being aware that, despite our well-wishing, we may very well be subjected to surveillance and processing of our oral and written communication without our consent-all made possible by gigantic physical infrastructures. If our data has become the mirror of our deepest selves, today's mega data centers are the storehouses for our collective digital soul [9].

Openness is one of the elements under greatest attack. There are two underlying factors:

(i)that which would affect the possibility of developing openness through programming

(ii) participatory flexibility

The first factor is related to the origin of the Internet itself: the idea of a cooperative network open to contribution, modification or improvement by all, is a core value in the shaping of the Internet as a network of networks.

The second factor is a techno-political product which facilitates flexible participation. Users can connect or disconnect whenever they want, modulate their degree of involvement and choose from a wide range of themes and activities to invest their time in. Free software, pro net neutrality movements and radical online participation actions are manifestations of an open imaginary of the shared that challenges established notions of private property and commodification.

Online commodification and centralization processes pose a serious threat to Internet glasnost. Different scholars have put forth different strategies for overcoming such challenges. One proposal is the principle of separation of powers, designed to keep the different factions of the information economy at a healthy distance from each other-much like the checks and balances system designed to maintain the power balance between the executive, legislative and judicial branches of government [10]. McChesney and others point out that capitalism-in the shape of growing corporate monopoly - is pitting Internet against democracy. In his recent book, Digital Disconnect: How Capitalism is Turning the Internet Against Democracy, McChesney points out that Google now controls close to $70 \%$ of the market $-97 \%$ in the case of Internet searches using mobile devices. Microsoft Windows runs on $90 \%$ of computers worldwide, despite 
fierce competition from Apple’s Mac and Linux. Apple, via iTunes, holds a whopping $87 \%$ market share of digital music downloads. Ninety percent of smartphone sales are split between Apple and Samsung [11]. This kind of network muscle puts a chokehold on innovation, as corporate Goliaths strive to turn the Internet into a set of predefined, creativity-reducing applications. This does not imply that hackers and other groups or individuals can continue to impact the Internet; but the ecosystem is increasingly restrictive and, in such a context, the influence service providers wield cannot be ignored.

\section{CONCLUSION}

Common too are cases of violation of one of the fundamental pillars of scientific knowledge-building: making the results of research available to the scientific community. Such was the case of a paper on the popularity of YouTube by the University of Cambridge and Google [12]. The use of patents to impede Internet innovation and stunt the development of new technologies is a very real concern. Google paid 12.5 billion dollars for Motorola in 2011 with one thing in mind: the 17,000 patents that came with the deal. Smaller companies simply cannot afford lawyer fees for never-ending lawsuits, much less the kind of money it takes to purchase tens of thousands of patents [13] Intellectual property disputes and the buying out companies for their patents are innovation-impeding trends which increasingly raise concerns regarding the basic premise that Internet is a collaborative construct.

With regard to trends towards more flexible forms of participation, we should avoid over complacency. As Terry Eagleton reminds us, "right when we started to think small, history started to act big." 'Think globally, act locally' is a familiar progressive/leftist slogan; yet we live in a world where the political right acts globally while the postmodern left thinks locally [14]. While this does not imply that flexibility with regard to commitment is negative per se, it does mean that real societal transformation calls for more than just clicks-as the $15 \mathrm{M}$ experience in Spain demonstrated. The 15M movement itself developed a culture of flexible, organized participation aimed at bringing a series of proposals to fruition. Close attention should be paid to the movement's triumphs and shortcomings, its pedagogical legacy. The movement culminated in proposals such as Democracy 4.0 [Democracia 4.0], envisioned as a veritable Trojan horse within the capitalist representative government intended either to attract the vote or to draw attention to inherent structures of domination [15]

Internet improves expectations for democracy and represents a significant step forward for the exchange of ideas and knowledge. The conditions we have discussed thus far-ambiguity, uncontrollability and openness-are indicative of a techno-politically guaranteed emancipatory process. Internet empowers a new conception of freedom that connects with the Athenian notion, eleutheria, breaking the chains of wage labor grounded in philosophers like Locke. In contrast to Locke stand the democratic Athenian polis, where the citizens were the producers; a state in which the civic community-which included both producing and appropriating classes-excluded relationships of domination or dependency between them (Meiksins Wood, 2011: 49).

Internet opens the door to a new eleutheria: a Greek notion of freedom which does not separate politics from economics or confine democracy behind strict political borders.

Freedom is a questionable concept in such a context. The Internet's deeply entrenched commodifying and centralizing processes are shielded in free-market capitalism-which capital itself recognizes as being its backbone. Capitalist processes fuel a commodifying and privatizing conception of the Net which, in turn, serves as a framework for limitations to Internet freedom. This philosophical approach to Internet is governed by a set of values which replicate the hegemonic forces at play in all other areas of reality. One of the greatest points of tension in this debate is the ideological and cultural direction Internet is taking; in other words, the question of hegemony and its consequences in both the real and cyber worlds. Both are inextricably linked and significant as capitalist strategies for appropriation of the Internet.

\section{ACKNOWLEDGMENT}

This paper was made possible by Research Project Proyecto de Excelencia de la Junta de Andalucía, Revolución Digital y Audiovisual y democracia.

\section{REFERENCES}

[1] D. Rotman. (2014). El día que Silicon Valley se convirtió en la meca de la desigualdad. [Online]. Available: http://www.technologyreview.es/printer_friendly_article.aspx ?id=463 00

[2] V. Mosco, To the Cloud. Big Data in A Turbulent World, Boulder: Paradigm, 2014.

[3] M. Padilla. (2013). Entrevista sobre el kit de la lucha en Internet. El Diario. [Online]. Available: http://www.eldiario.es/interferencias/Internet-politica-complejidad_6_ 88951108.html

[4] F. J. Bellamy, R. McChesney, "The Internet's un holy marriage to capitalism," Monthy Review, vol. 62, no. 10, 2011.

[5] L. Lessig, El Código 2.0. Madrid: Traficantes de Sueños, 2009.

[6] Ippolita, El acuario de Facebook. El irresistible ascenso del anarco-capitalismo, Madrid: Enclave, 2012.

[7] V. Mosco, To the Cloud. Big Data in A Turbulent World, Boulder: Paradigm, 2014.

[8] A. Blum, Tubes. Behind the Scenes at the Internet, London: Penguin, 2012.

[9] T. Wu, The Master Switch. The Rise and Fall of Information Empires, London: Atlantic Books, 2010.

[10] R. W. McChesney, Digital Disconnect. How Capitalism is Turning the Intenet Against Democracy, New York: The New Press, 2013.

[11] V. Mosco, To the Cloud. Big Data in a Turbulent World, Boulder: Paradigm, 2014.

[12] R. W. McChesney, Digital Disconnect. How Capitalism is Turning the Intenet Against Democracy, New York: The New Press, 2013.

[13] T. Eagleton, After Theory, New York: Basic Books, 2003.

[14] F. Jurado Gilabert, Nueva GramÁTica PolíTica. De La RevolucióN En Las Comunicaciones Al Cambio De Paradigma, Barcelona: Icaria, 2014.

[15] E. Meiksins Wood, De Ciudadanos A Señores Feudales. Historia Social Del Pensamiento PolíTico Desde La AntigüEdad A La Edad Media, Madrid: Espasa, 2011. 


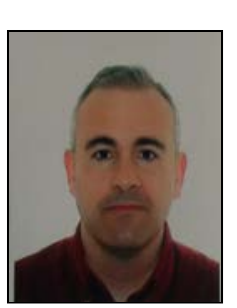

Rafael Rodríguez Prieto (Algeciras, 1972). Rafael holds a master in Latin American Studies (UNIA, Spain) and BA and MA degrees (licenciado) in anthropology, law and philosophy (University of Seville, Spain). Rafael was postdoctoral fellow at Harvard Law School (Cambridge, USA). He studied at YadVashem, Center for Holocaust Studies (Jerusalem, Israel), specializing in education and anti-Semitism. He holds a $\mathrm{PhD}$, european mention (Universitàdi Bologna-Universiteit Utrecht and Pablo de Olavide, Seville). The doctora thesis was defended at Universidad Pablo de Olavide, Seville. The president of the tribunal was Benny Pollack (Professor, University of Liverpool). The thesis dealt with radical participatory politics in London (Greater London Council 1981-1986) and Porto Alegre (The Participatory Budget). His research interests include critical legal theory, participatory politics, multiculturalism, anti-Semitism and the battles for control of the Internet. His work also concentrates on the political economy of communication, emphasizing the role media plays in capitalist societies. His recent books are Digital Chaos and Common Media (Caos digital y medioscomunes, with A. González, Madrid: Dykinson, 2014), Power and Internet. A critical analysis of the NET (Poder e Internet. Un análisis crítico de la Red, with F. Martínez,
Madrid: Cátedra, 2016) and Videogames: The digital explosión thatchangestheworld(Videojuegos: la explosión digital que está cambiando el mundo, Sevilla: Héroes de Papel, 2016). He published with A. Hadzelek, 'Movinets and the Future of Social Movements: How 15M and Occupy Revolutionised Political Protest', in: Essays 2014: Politics, Melbourne: Australian Scholarly Publishing, July 2014.

$\mathrm{He}$ is a political and legal theorist and professor (Profesor Titular) at Universidad Pablo de Olavide, Seville and distinguished visiting professor, University Technology Sydney (2015). Researcher, RCC James B. Conant Research Group at Harvard University (Media \& Democracy) and Vice-chair of Ideas \& Political Praxis Lab, a think tank on democracy. Rafael has been researcher or visiting academic at Brandeis University (USA), Istituto Antonio Gramsci (Italy), Instituto Paulo Freire (Argentina), London School of Economics and Political Sciencice (UK), Universidad Autónoma del Estado de México (Mexico) and the John F. Kennedy School of Government (Harvard University, USA). He has made presentations at Massachusetts Institute of Technology (MIT, USA), la UniversidadAutónoma de Baja California (Mexico) and Universidad Nacional de Rosario (Argentina).

Dr. Rodríguez Prieto has beenawarded "Huesped de Honor" by Universidad Nacional de Rosario, Argentina. 